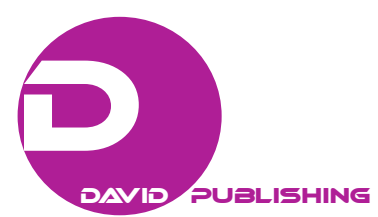

\title{
Money, Finance and Human Values, Lessons From the Twentieth Century
}

\author{
Mario Pines \\ University of Trieste, Trieste, Italy
}

\begin{abstract}
In the analysis of the present day crisis, the paper considers a result of commercial banks deregulation: blowing financial transactions, widespread new Keynesian flow of marginal monetary basis, jumpstarting financial instruments, short-term based financial program trading speculation. In this way, the research starts from the last market bubbles collapsed in the years 2000 and 2007-2008: dot-com, subprime and derivatives. Its results confirm the effect of the general persistence of wrong monetary policies, triggering irreversible liquidity, fiscal and interest zero rates traps. The conclusion is that an everlasting crisis is not the consequence of some isolate deregulation of some institution and markets activity in general, neither likely due to some new financial innovative product fallout. On the contrary, what surfaces in August 2007, is the result, after 40 years of monetary debasement and quantitative mismanagement, excessive faith in macroeconomics dangerous ideas and disregard of minor micro-economic laws, associated with the appearance of the huge Eastern competing world, once frozen in the planned economy, a global market oriented environment. The Western welfare State seems likely to finally collapse in a completely free surfacing new market economy.
\end{abstract}

Keywords: banks, financial crisis, backgrounds and Bretton Woods, gold standard, central banks

\section{Monetary Debasement and Quantitative Mismanagement}

The present paper explores the history and grounds of recent monetary turmoil considering some preliminary factors affecting the debasement of the US dollar in the year 1971 and the unexpected consequences arising from such a controversial decision.

After World War I and 30 years of unsuccessful efforts to reach a stable international payment system, the recurring clearing agreements, the final establishment of the Bank for International Settlements in Basel, the GATT and the World Bank, Europe seemed to be finding an alternative solution to the autarchy and tight custom barriers, which led to World War II.

Several monetary plans, drawn and discussed at Bretton Woods in July 1944 and, after World War II: the European monetary union, the Werner plan, the issuing of the European Currency Unit (ECU), the final financial markets liberalization in the year 1990 culminated in the EMS and the Euro project. The European monetary system led to the issue of the Euro that made likely a debased monetary instrument as final unique solution, within the Single European Payment Area run over the Swift-Target platforms. According to the

Mario Pines, full professor, Department of Financial Markets and Institutions, University of Trieste, Trieste, Italy.

Correspondence concerning this article should be addressed to Prof. Mario Pines, Department of Financial Markets and Institutions, University of Trieste (DEAMS) Via dell’Università, Trieste 134123, Italy. 
fifth recommendation of the Marxian Manifest, the Central Banks and the banks in the system become a base for a social accounting facility network. The monetary quantity could then be easily adjustable, according to the plan provisions: any deficit spending monetary policy would be possible, within a capitalistic microeconomic framework; fiat money would provide all the financial means necessary in a hyperinflation environment.

The Asian surfacing economies, after the monetary disorder following the Camp David panicking weekend dollar's debasement, 15th August 1971 (Ferguson, 2008), may be considered as one of the fallout effects among which:

- the oil embargo and the surge of its price within the OPEC alliance;

- the Islamic demise of the socialist ideology during the 1970s, leading to the Jihad, and related Afghanistan and Islamic wars;

- within the Commonwealth of Independent States (CIS), and globally accepted general shift towards a single market economy, have upturned the World basic order which has emerged since the Yalta Pact 1945, when the Western American revolution seemed to be definitely prevailing;

- the huge financial slumps and markets' disorder and corruption on a global basis, which are the final unavoidable consequence.

The collapse of the Soviet Union, the break down in 1979 of the Russian cooperation with the Arab world, the Afghanistan invasions and, most of all, the China repudiation of the Cultural Revolution, as designed in the Lin Biao's theoretical red booklet, left the Adam Smith capitalistic principles took over the whole Asian Hemisphere. In an exclusively market oriented perspective China, her Great Leap Forward was proposed. Such model allowed a successful development epoch, which attracted most of the world industrial structures, taking advantage of the locally inexistent welfare-additional Western pattern. Therefore, the Western world had to face the monetary tsunami and the Asian market competition; meanwhile the classical financial speculation took over the booming financial markets, blowing and bursting bubbles everywhere.

\section{The Twentieth Century Monetary Mismanagement Fallout}

The reconsideration of the "900 century monetary policies", formulated by Mundell in his Nobel Prize ceremony message, in Stockholm in the year 1999 (Mundell, 2000) and the Triffin fine tuning of the Dollar Dilemma (Triffin, 1960), are segments in the same monetary everlasting dispute. It initiated originally in Genoa, in April-May 1921, at the International Economic Conference, its substance and role, more than ever about the international payments system, have become the ever-lasting issue, going on until today in the definitively global imbalances scenarios.

In the Bretton Woods Henry Dexter White, at the Mount Washington hotel, in July 1944, Steil (2013), opposed to Maynard Keynes the White plan, drafted for the USA Treasury Secretary Henry Morgenthau Jr., designer and architect of the New Deal scheme drawn in 1933, that was de facto reintroducing a pseudo gold standard. Under the dollar coverage, made possible by the large American holdings of Gold reserves secured in Fort Knox, the demise of the New Deal and the common desire to erase general national rivalries and custom barriers, became the real issue. The Conference drafted the IMF statute, the World Bank, and the GATT agreements, definitive structure of an international payment system survived over the downfall of the pseudo gold standard. The purpose was to avoid the nationalistic competition and the unsuccessful "clearing agreement payment systems" as enforced during the previous 20 years with an "Austerity prevision for potentially defaulter members". 
On the verge of a monetary excessive growth, on 15 August 1971, Nixon repealed the US dollar external convertibility, as fixed in 1944, sentencing the second monetary debasement in the same century. So sentencing the definitive termination of the already secular gold standard and the monetary metallic gold basis really enacted during the Glorious Revolution "Stop of the Exchequer" Act that was, by then, definitely over (Quinn, 1996). All what happened thereafter in finance, micro, and macroeconomics, and in the bubble blowing and bursting developments, has a single common origin and sole evolving drive. It stems from the paper fiat money revolution and the deficit spending monetary archetype (Blyth, 2013), overwhelming and expanding unorthodoxy monetary policies that, at the end of the day, have shown little, or even negative effects on output, consolidating the everlasting depression started on that 15 August 1971.

During that weekend, on 15 August 1971, the President and his advisers, in a panicking and confused session in Camp David, dropped the pseudo gold exchange standard and therefore the dollar gold parities, with a brief communication to the Secretary of the Treasury J. B. Connally, announcing the "temporarily" demise of the Bretton Woods gold exchange mechanism. A softening monetary policy started the seventies stagflation and eighties interest rates turbulences, until the black Monday's fall of the Dow Jones index in October 1987, when it slipped from $23 \%$ to $1.738 \%$. A recurring everlasting credit facility, endorsed by Alan Greenspan, who supplied liquidity through all the roaring nineties, brought the D J index to the unexpected level of 10,500 in the year 2000 (Mallaby, 2016). The Gramm Leach and Bliley Financial Services Modernization Act of 1999, erasing the structural Glass Steagall Act, promoted the merger of the commercial and investment banking industry, blowing and bursting the final sub-prime and derivative bubbles, after the first dot-com bubble eruption in the year 2000.

After the President Nixon external gold convertibility repudiation, the 1970s, led into new phenomena: an increasing monetary expansion, a deficit spending global pattern prevailing attitude and an economic stagflation, in contrast with the previous Philips and Taylor curve normal expectations. As far as year 1696, the English Parliament, besides the silver coinage, had established a price ceiling for gold. Except this limited price band for gold, England earlier introduced a legally fixed, bimetallic standard that favored gold in domestic circulation by undervaluing silver relative to gold. These tensions between substitutes were still at work for centuries before England converted silver coins into token money and adopted an official gold standard in 1717, after the "Stop of the Exchequer" Act in 1671 (Horsefield, 1982) when the deficit spending policies became illegal. However, the ruinous strain on England's silver standard had begun with William III and the Glorious Revolution, which opened the doors to the great monetary and economy stability through the basic Hume self-balancing model: the price-specie flow mechanism, the gold-standard era. The "Stop of the Exchequer" Act was the fundamental objective rule avoiding any possible deficit spending policy.

Since April 1921, Ralph Hawtrey (1919) played a key role in forming the guidelines for the Genoa Conference attempting to explore ways and means to a stable return to the gold standard. Ralph Hawtrey and Gustav Cassel brought, therefore, their reflections as members of the Finance Commission, which was attending the 1921 International Economic Conference in Genoa. They addressed the relevant operators about the monetary perspective, in the aftermath of World War I debasement, out of the gold standard, arousing undisputable arguments in the everlasting dispute about internal and external imbalances, money, savings, investments, finance, profit sharing, and the new welfare State income taxation, in the New Deal pending legacy.

At the very beginning, the historical first observer and interpreter of these specific monetary angle seems to be (Simmel, 1898) expressing his philosophical consideration about the objectivity of the money benchmark 
value. He expresses the first potential conflict about two opposing modern monetary and financial guiding principles: is money a token, a symbol without any value by itself, or must it be a value, in order to carry on sound services of measurement, exchange and become a consistent saving medium? The nevertheless unsettled dilemma lies unresolved, after the stalling cold war, 70 years of stalemate in the search of a way out to an endemic economic financial crisis, with a single interval during the gold-exchange standard (the pseudo gold standard). It happened without any apparent signal in an endless row of disappearing collapsing currencies debasements, first gold itself, then the commodity de facto oil standard, finally out of the trust and faith the State, a plane debtor with several recurring defaults, and crony economies spread worldwide.

There is just one single row of connected events, starting with World War I gold debasement, on 1 August 1914. The closure of the Stock Exchanges worldwide rouses the primordial legal tender of a debased fiat emergency monetary unit. Despite the splendid gold standard balancing mechanism, outlined in the Hume model, adjusting automatically the national imbalances in both external and internal directions and harmonizing the real interest rates system, in a full market economy at same time, the monetary policy, promoting deficit spending, resulted in a temporary compromise in most modern democracies resulting in huge public debts. Simmel depicts as potentially impracticable and unsuccessful any legal tender system of monetary transactions in a plural currencies system, unless money finally becomes a clearing token in a single planned economy, which requires a utopian unrealistic totalitarian single global state.

In a variety of national monetary systems, any different currency, seeking to become an international mean of payments, must smoothly meet a generally accepted trusted benchmark value basis. So is it for silver, oil, wampum, sheep, shell, gold and any generally accepted monetary instrument. The North America colonists adopted wampum as their own currency; however, the Europeans with more efficient production of wampum caused inflation and ultimately the obsolescence of wampum as a currency.

\section{The Keynesian Model From Genoa to Bretton Woods and Further}

The Keynesian General Theory, stemming from the German experience in the aftermath of World War I scenario: the war consequences defeated by public deficit spending and the completion of a large-scale public infrastructure projects. Germany initiated immense infrastructures works under a full pressing unemployment condition, in an economy destroyed by the war. The landscape represents a unique rare setting likely to respond to a monetary immense stimulus. The deficit spending after the introduction of the RM (Renten Mark), after the weak Weimar fight against the hyperinflation, permitted the huge investment expansion that actually worked and gave Keynes a real model of his General Theory and deficit spending ideas, it happened in the year 1936, but never happened thereafter.

The Keynesian model became the deepest and hardest to remove, justification to the debased deficit spending worldwide public models that started in August 1971. The phenomenon surfaced in the identical post World War II scenarios, when Keynesians and post Keynesians promoted growth monetary policy packages that end up, lately, into the final Japanese last Grail (Koo, 2008) Abe-economics. Even endplay negative interest rates failed to stimulate new economic activity and promote productions in a zero sum game framework when, from a microeconomics point of view, taxation has been eroding most profit expectations in a too expensive welfare social Western environment.

In 1979, a global transformation started in Teheran with the Iranian revolution that overthrew the Pahlavi dynasty under Mohammad Reza Shah Pahlavi, and led to its eventual replacement with an Islamic republic 
under the Grand Ayatollah Ruhollah Khomeini. In the same year, the Roman Conclave chose of a Polish Pope, coming from a Warsaw pact State, over the iron curtain. Furthermore, in the year 1979, the Deng reform of the Chinese social economic system promoted the abolition of the Mao Cultural Reform, with the mutual recognition between China and the USA, the abolition of all the social cooperatives and the introduction of the rule of law, private property rights. In the same year in UK, there was the appointment of Mrs. Thatcher, after the demise of Mr. Callaghan as labor leader; who lastly dictated: "We used to think," James Callaghan, told the Labour party conference in 1976, "you could spend your way out of a recession and increase employment by cutting taxes and boosting spending. I tell you in all candour that this option no longer exists." "In December 1979, the invasion of Afghanistan by the Russian troops took place on the Christmas day eve, after the Muslim world broke down all the previous solidarity treaties with the Warsaw Pact, and the Amin regime took over the power in Kabul, Afghanistan. These major factors, closing the huge long inflationary period after the first worldwide monetary gold debasement, are definitely all its consequences.

The conflicting widespread macroeconomics theories, stemming from the 20th century first great depression, the disregard of microeconomics and its guidelines, in most market-oriented economies, relevant from a classic market efficiency preconditions point of view, in facing the monetary fallout effects, have led to a dead end path, now called secular recession. Through an obsolete indisputable prevailing monetary policy and final unorthodox quantitative easing attitudes, supporting any specie of deficit spending, everlasting erroneous guidelines in management and widespread corruption policies, in the developing crony political arena, have prevailed explaining the present turbulence time (DiMartino, 2017).

In the "Papers relating to the International Economic Conference", held in Genoa in April-May 1922, the first resolution, in the Report of the Second Commission (Finance) states: "The essential requisite for the reconstruction of Europe is the achievement by each country of stability in the value of its currency."2 Furthermore, it is determined that "Banks, and especially banks of issue, should be free from political pressure, and should be conducted solely on line of prudent finance." The clear view of the Commission foresaw that all European currencies should be based upon a common standard which in Genoa was agreed to be nothing but gold, not being by then, perceivable the idea of a single debased currency as instrument of international payments.

The first global effort to reinstall the gold base and eventually to support the fiat money circulation is supposed to be the culprit of the great depression, which started in the year 1929, after the twenty monetary roaring years (Friedman, 1961). At that time, most of the industrial brands came out of a new booming market, which reached its highest value in September 1929, in the expansionary effect of an increasing and enlarging fiat monetary basis. In Europe, the reconstruction and recovering plans, and the incapacity to establish a new international payments system, led to the collapsing payment clearing systems. Firstly negotiated bilaterally, then multilateral through slow steps and a single depositary bank, the BIS (Bank for International Settlements) located in Basel, trying to settle bilateral imbalances in neutral territory and structures and depositary of most of the existing gold balances, the system was working for about 20 following years.

The deep monetary policy debate in Germany, about the deficit spending in the rearmament phase, was the

2 Papers relating to International Economic Conference, Genoa, April-May 1922, London. 
central point that caused the dismissal of Hjalmar Horace Greeley Schacht, from the Presidency of the Reich's Bank and the large consequent "Keynesian” monetary base growth. This fact marked the General Theory that, under very special circumstances and short time reflections, recalled the huge economic growth and recovery of the previously defeated State, which repudiated its war debt but became the single country that did not suffer the unemployment and depression phases in the thirties.

All the other European nations suffered heavily in the aftermath of the first modern fiat money legal tender supply and the unsuccessful clearing unions that did not allow a smooth reconstruction of new international trade and settlement reliable monetary systems. This circumstance led to the foreign exchange fluctuations and unsettled internal and external balances.

The raising of custom barriers, trade quotas, and foreign exchange state monopolies, induced from the recession to the great depression that stems only from the new foreign exchange in the Bretton Woods agreements, as outlined by Henry Dexter White and Henry Morgenthau in the Mount Washington Hotel in July 1944. The Marshall plan and the European Monetary Union in 1952 allowed a smooth reconstruction of the international payment system and the return to the pseudo gold system through the external convertibility, a gold benchmark for Central Banks of the States progressively adhering to the IMF agreement.

During this period, the world trade reached enormous volumes of interexchange and the economic growth was reaching unforeseen levels, Italy was in an economic boom, the Italian miracle was the common definition of the after war recovery, and the lira won in 1959 the Oscar prize for the best stable currency. Japan became a huge superpower with a full first place listing of its banks in the yearly ranks for the sector.

\section{The Dollar Debasement and the Banking System Crisis}

The final debasement of the dollar, stemming from a frenetic Camp David weekend meeting, when the gold base was still formally retrievable trough Central Banks at 35 dollar an oz. is due to the excessive large issuance of paper bills over a decreasing base of gold reserves at Fort Knox, Fed deposit. The dollar Triffin Dilemma, after the Triffin realistic study of the future of convertibility (Triffin, 1960) is a perfect prediction of what will happen in Camp David in 1971, when the brief announcement of President Nixon triggers the slowly but deeply following fifty years lasting depression.

Triffin in October 1959, as a Yale professor, sat in front of the Congress' Joint Economic Committee calmly announced that the Bretton Woods system was doomed. The dollar could not survive as a world reserve currency, without requiring the United States to run ever-growing deficits on one side and to keep as well ever-growing quantities of gold in order to preserve exchange rates stable on the other side, considering the parity assumed in 1944.

On the other side, Jacques Rueff (1971) since the 1960's a major supporter of a return to the gold standard and the critical use of the dollar as a unit of reserve as perceived in the Bretton Woods agreement warned that the growing monetary leverage would finally cause a worldwide inflation. A member of the Académie des Sciences Morales et Politiques, Rueff was elected to the Académie française in 1964. Foreseeing the emerging European Community Common Market, Rueff recommended cutting barriers to competition in his second report. Along with co-writer Louis Armand he was helped by an ad hoc committee of experts to draw the blueprints of the "Plan Rueff-Armand", that was published in 1960. The full title of the report is "Report on Suppressing Barriers to Economic Growth”. 


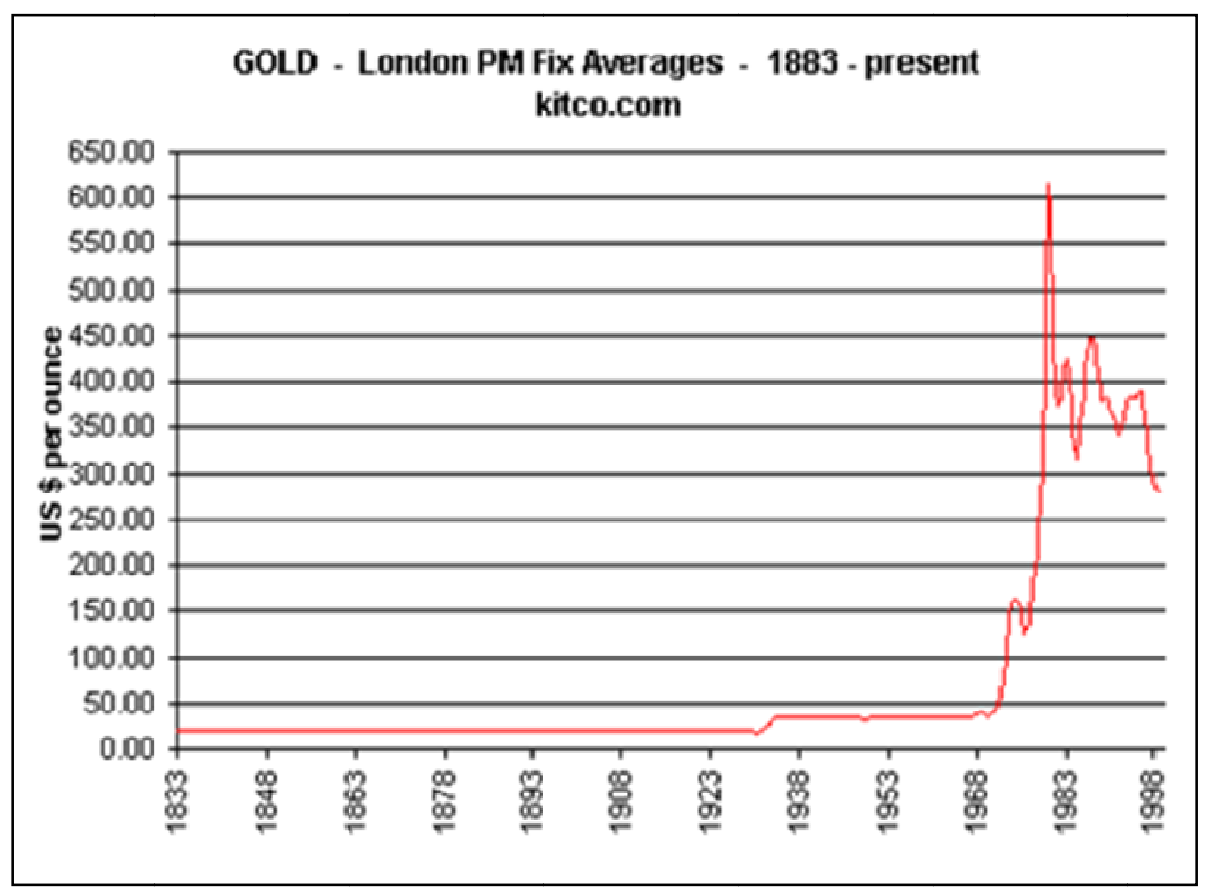

Figure 1. Gold-London fixing-1833 present.

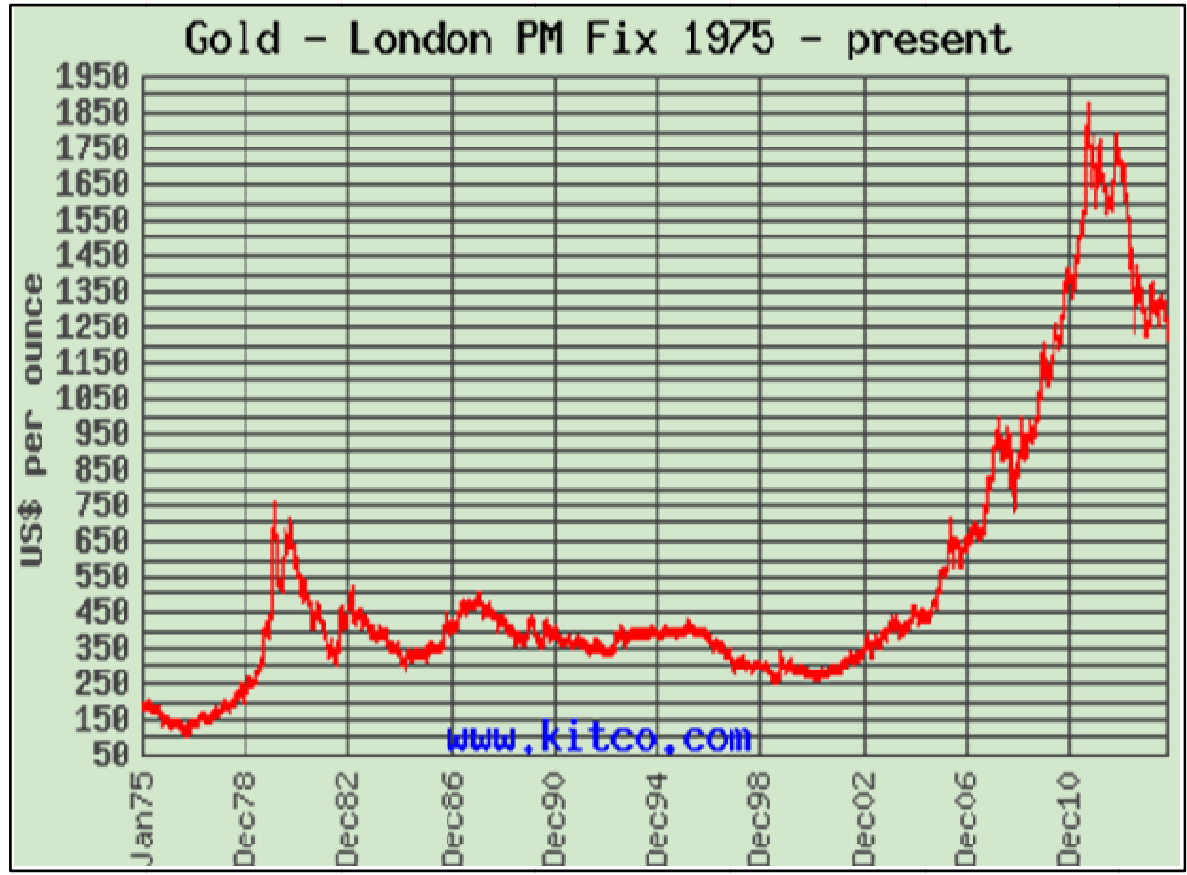

Figure 2. Gold-London fixing-1975 to present.

This austere scientist was the Belgium-born Robert Triffin, and the history proved that he was right. The Bretton Woods system collapsed in 1971 and today the dollar's acceptance as a reserve currency, has forced, or permitted the USA to run the largest current account deficits in the history. When the gold coverage was removed, the convertible minor currencies lost their value and the oil exporting countries and their larger exporters, trusted the dollar as the Noah's Ark. Everywhere started the research of some solution but none was able to survive or substitute the sinking dollar. 
The Bancor, the special drawing rights, the ECU (European Currency Unit), the Euro finally, tried as reserve currency instruments without any success with the world Central Banks reserve, that have been de facto always dollar denominated, as well as most of the relevant trading commodities: coffee, oil, gold that have constituted a de facto benchmark.

After the ten years of WIN (Win Inflation Now) slogans when both Phillips and Taylor predictions had lost their meaning, in September 1980 President Reagan enacted a special Gold commission, chaired by Donald Reagan with single scientific member Anna Schwartz. The Reagan Gold Commission had an almost mythic status in the history of American monetary policy. As award-winning author and economic historian, Brian Domitrovic observed in his Forbes column, "The First Gold Commission Scared the Dickens out of the Fed.”3

The minority report of Paul and Lehrman, did recommend gold, and it remains to this day one of the scintillating documents of recent public policy. It might as well be a blueprint for 21st century monetary reform.

The Commission Minority Report, The Case for Gold, signed by Reagan Gold Commissioners Lewis E. Lehrman, founder and chairperson of the Lehrman Institute, remains in print and is available from multiple sources. The Majority Report, authored by Milton Friedman collaborator Anna Schwartz, mostly academic interest, also has been available in PDF form, to the Web by GoldenSextant.com. In the cold war atmosphere, when the major gold producers were Russia and South Africa, the case was for a convenient 35 US dollars an ounce price to remain as it was.

Starting from the periphery, spreading towards the southern and eastern countries of the Planet, at the end of a monetary Greenspan easing policy, a new stagflation environment led to the final bursting central bubbles, since the year 1987.

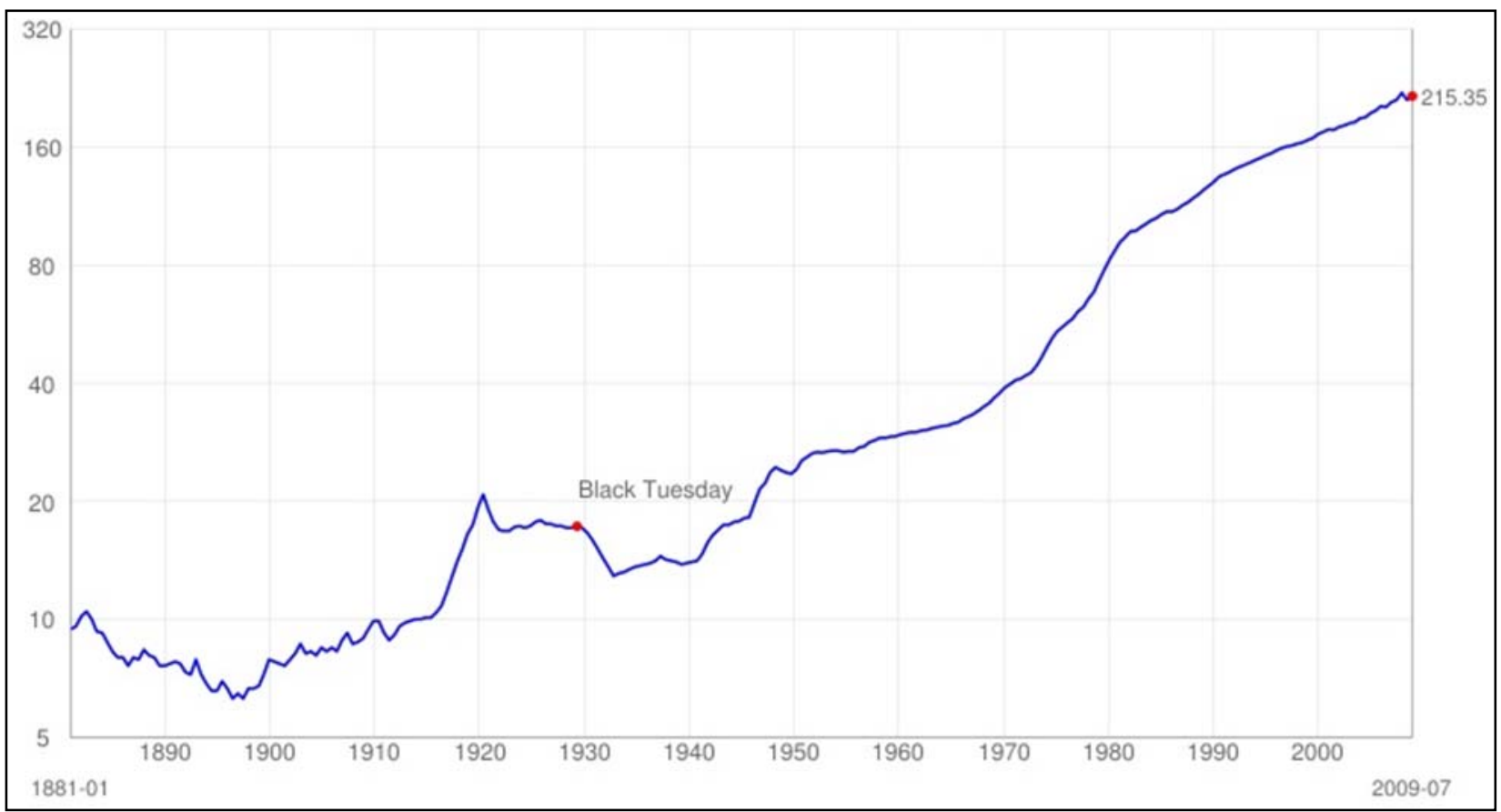

Figure 3. Consumer price index after the debasement. Source: http://xspy.com/consumer-price-index-cpi/.

3 
The crisis started at the exit of Paul Volker leadership up to the year 2000 dot-com bubble, to the 2006 sub-prime, and to the final derivatives financial crack down in the year 2008, and is still in force.

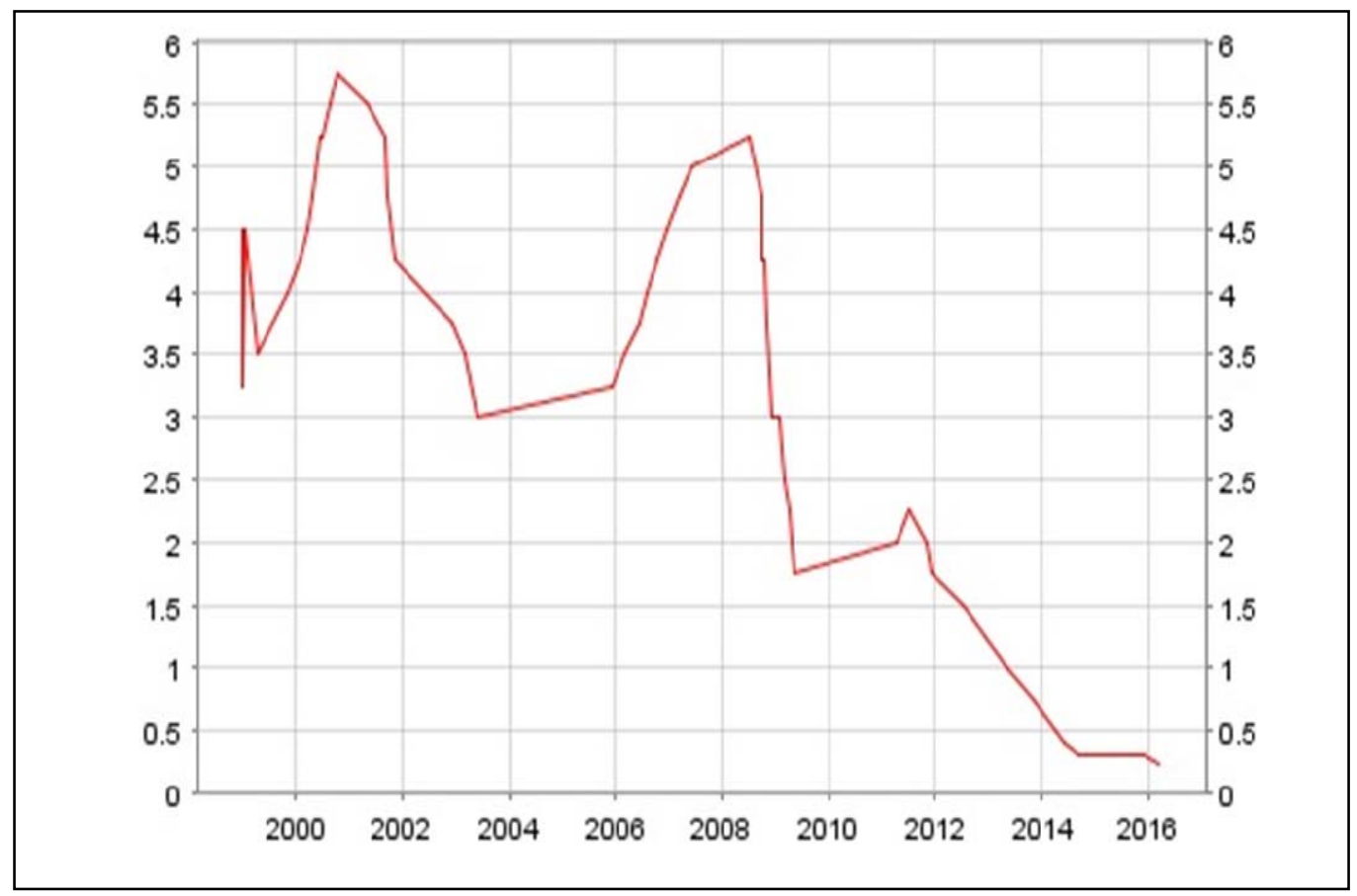

Figure 4. Interest rates at source. Source:

http://sdw.ecb.europa.eu/quickview.do;jsessionid=90F59DE0F3FBC376F3995593C9A93964?SERIES_KEY=143.FM .B.U2.EUR.4F.KR.MLFR.LEV.

The supply side economics, the Smithsonian Institute remedies, and the constant growth of the market indexes, have blurred the attention of most economists from the deep inconsistency between the monetary expansion remedies and the absence of inflation, especially during the Greenspan tenure at the FED. We can now fairly explain the absence of inflation, in a generally deflationary framework, starting during the eighties, with the determinant overwhelming prevalence of Eastern low labor industrial costs, that have been out-crowding the generally higher Western production costs in the markets, mainly affected by large welfare costs missing in the Eastern competing economies.

In March 2008 questionably, the FED started to apply the provision No. 3 of the Sec. 13 of the Federal Reserve Act, on December 23, 1913, that allows discretionally FED emergency monetary unlimited intervention (Quantitative Easing) in too big to fall hypothesis. In March 2008, in the taking over of Bear Stearns, J. P. Morgan was granted a 29 B. facility, which started the expansionary growth of the monetary basis. Up to an amount never seen before, through the TARP (Troubled Asset Relief Plan) and QE (Quantitative Easing) systemic salvage of the American automotive, insurance, and banking industry, was a consequence of the monetary basis M0 rising to unbelievable levels. The cultural huge swift from a market economy to a banking profile of social accounting center, was the first sign of the final debased fiat money collapse. Were not for the fact that on the global market, the dollar has become to survive as the last single currency unit, capable of a residual monetary function with an apparent coverage allowed by the oil barrel as that market remains denominated in dollars, the barter would have resurfacing in the trade transactions. 


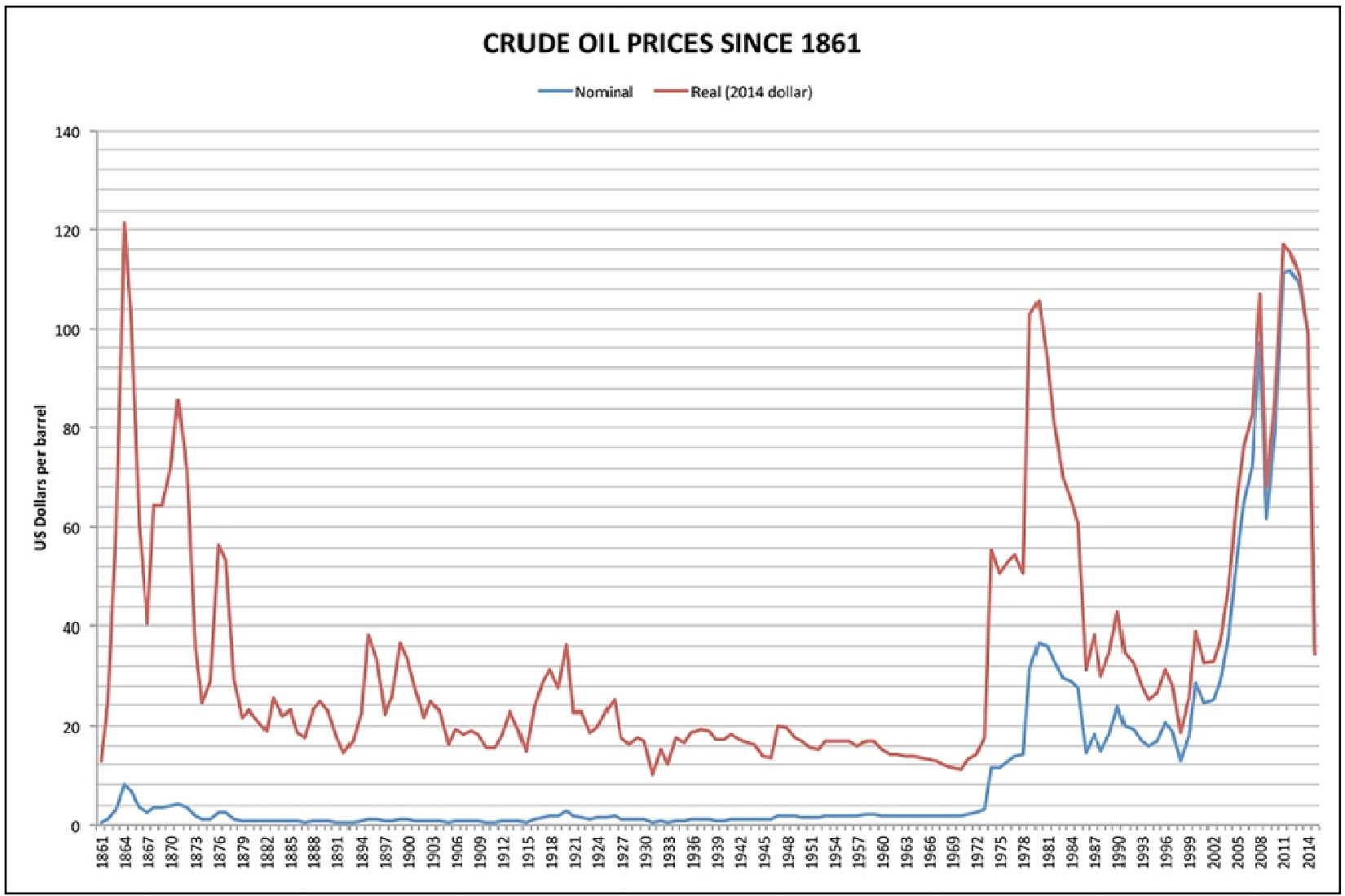

Figure 5. The transitional oil standard 1971-2016. Source: By Jashuah-Own work by uploader, data from BP workbook of historical data, CC BY-SA 3.0, https://commons.wikimedia.org/w/index.php?curid=20745151.

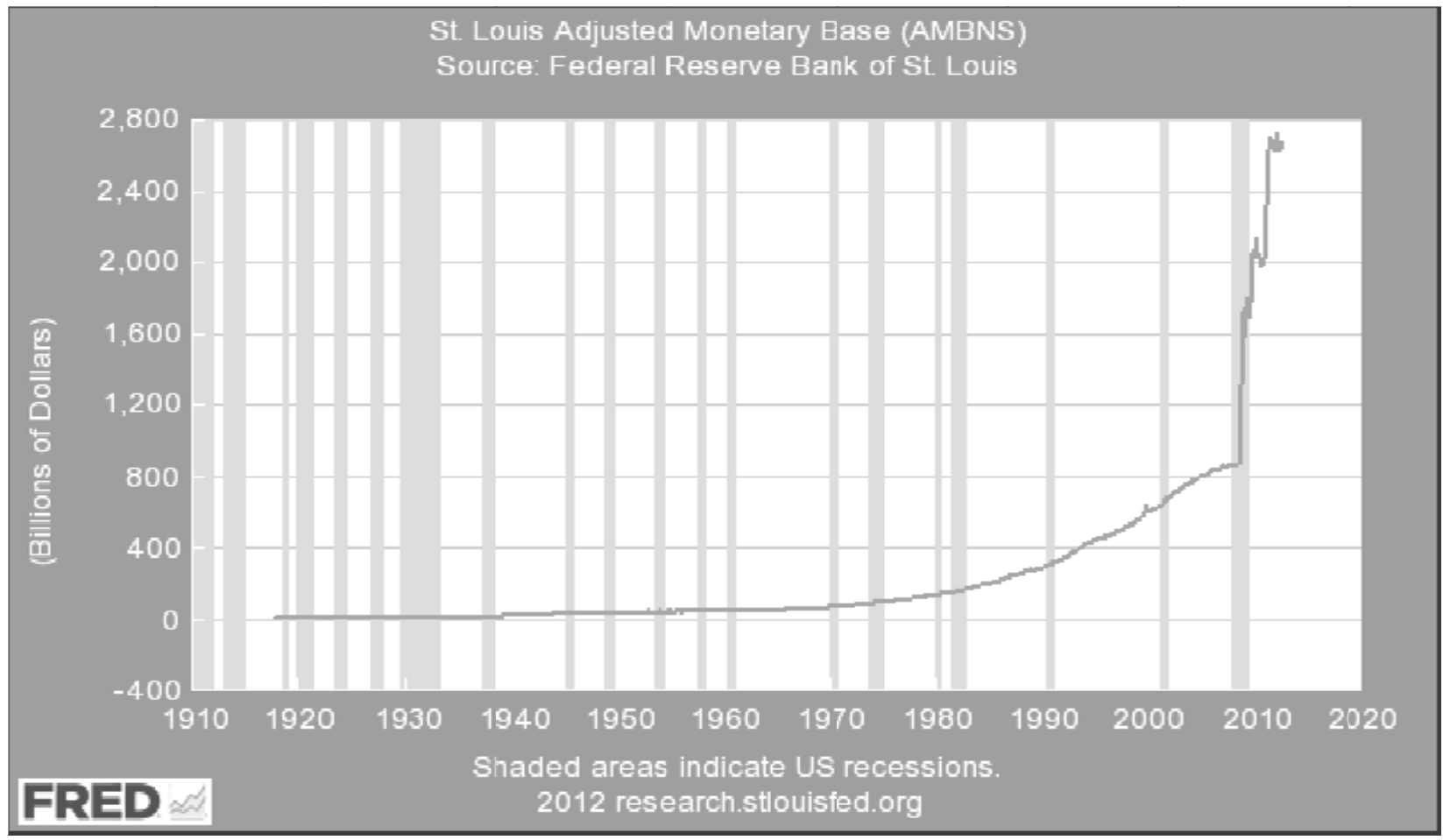

Figure 6. USA monetary base. 


\section{Conclusions}

China's economic huge growth, produced the largest market economy in the fallout of the Cultural Revolution, there is not a single model explaining such a fast and unexpected economic growth in our classic and modern theories, according to the models worked by the modern development economists. As stated on the occasion of the 100th anniversary of the birth of Jacques Rueff, address formulated by Lewis E. Lehrman at the parliament of France (Assemble Nationale) on November 7, 1996:

The overthrow of the historic money of commercial civilization, the gold standard, led, during the next decade, to the great inflations in France, Germany, and Russia. The ensuing convulsions of the social order, the rise of the speculator class, the obliteration of the savings of the laboring and middle classes on fixed incomes, led directly to the rise of Bolshevism, Fascism, and Nazism. They were, linked to floating European currencies, perennial budgetary and balance of payments deficits, central bank money printing, currency wars and the neo-mercantilism they engendered.

Same reasoning comes from the statement of Dr. Zhou Xiaochuan, Governor of the People's Bank of China, on 23 March 2009:

Theoretically, an international reserve currency should first be anchored to a stable benchmark and issued according to a clear set of rules, therefore to ensure orderly supply; second, its supply should be flexible enough to allow timely adjustment according to the changing demand; third, such adjustments should be disconnected from economic conditions and sovereign interests of any single country.

Monetary policy has become a very tough political issue, since the generalization of fiat money as legal tender without any intrinsic value base. As Koo (2009) clearly wrote in his The Holy Grail of Macroeconomics: Lessons from Japan's Great Recession, the short-time effects of macroeconomics policies are not clearly analyzed and verified on a long-time basis, before the Camp David 1971 decisions. Now they are fully perceivable in their dramatic consequences, a corrupted crony capitalism and political behavior on one side and a fanatic refusal of life, work, and sacrifice on the other trough the suicide bombing terrorism, which replaced the previous cold war.

The following financial turmoil has moved in various different directions, with several environmental events: the inflationary seventies, the markets index booming eighties and nineties, the crisis in the last nineties. The financial markets booms led to a misinterpretation of the derivative remedies and their effect over the financial intermediaries with huge bank crisis and the unpredictable irrational investors' euphoric behavior.

States insolvencies and a huge general unemployment led to a definitive Western progressive depression, under the pressure of the huge Asian expansion and low labor costs, free of micro economic boundaries. From the Koo's angle, the contraposition of a free market economy and a State presence in the economy through Keynesian long-term remedies is leading Japan and most Western economies to a dead end tunnel. The public sector, while dismissing its management and intervention role, is conditioning the prices and costs structures through the widening welfare State, due to the crisis itself.

The author has to admit that, as most free-market economists, the author is confused by the favorable comments Friedman has later made about Keynes. The leader of the Chicago school has always been a strong anti-Keynesian. His Monetary History of the United States clearly denies Keynes's thesis that the capitalist system is inherently unstable if not stimulated by the State. The book shows that the Fed's unilateral policies, not the free entrepreneurs, caused the Great Depression, somehow in line with Mundell. Friedman's permanent-income hypothesis modifies Keynes's consumption function and undermines the case for unlimited 
progressive taxation. His natural-rate-of-unemployment doctrine denies any long-run trade-off between inflation and unemployment (the Phillips curve), particularly after the "70s experience of the long lasting stagflation”. In Capitalism and Freedom, Friedman challenges the effectiveness of the Keynesian multiplier and declares that the federal budget is the "most unstable component of national income in the postwar period". The most recent booming public debts worldwide are confirming the emptiness of the deficit spending theory, as long as the micro-economy is performing correctly in explaining and classifying the huge recent China's growth on an average rate of GDP close to $8 \%$ on an annual basis since the demise of State planning.

The new challenging consequences, after the 2008 final demise of the monetary stability, are heavily and unwisely, loading up the huge public debt and the recourse to the monetary stimulus that feeds itself. The fade has been setting fatal unwise perspectives over interest rates become negative. Monetary functions, especially as saving vehicles, and potential inflationary waves or Central government wide spread defaults, have become "Being the only game in town, central banks will find it ever more difficult to keep everyone on a road that is challenged in delivering the desired economic and financial objectives.” (El-Erian, 2016, p. 211).

\section{References}

Blyth, M. (2013). Austerity: The history of a dangerous idea. New York, NY.

DiMartino, B. D. (2017). Fed up: An insider's take on why the Federal Reserve is bad for America. New York, NY: Barnes \& Noble.

Domitrovic, B. Retrieved from http://www.thegoldstandardnow.org/brian-domitrovic-bio

EL-Erian, M. A. (2016). The only game in town: Central banks, instability, and avoiding the next collapse. New York, NY: Random House Audio.

Ferguson, N. (2009). The Ascent of Money. London, UK.

Friedman, M. (1961). Real and pseudo gold standard. The Journal of Law \& Economics, 4, 66-79.

Hawtrey, R. G. (1919). Currency and credit. London, UK: Longmans.

Horsefield, J. K. (1982). The “stop of the exchequer” revisited. The Economic History Review New Series, 35(4), 511-528.

Koo, C. R. (2009). The holy grail of macroeconomics: Lessons from Japan's great recession. Singapore, SG: Wiley.

Mallaby, S. (2016). The man who knew. New York, NY: Penguin Press.

Mundell, R. (1999). A reconsideration of the twentieth century. Retrieved from: http://www.columbia.edu/ ram15/nobelLecture.html

Quinn, S. (1996). Gold, silver, and the Glorious Revolution: arbitrage between bills of exchange and bullion. The Economic History Review, 49, 473-490. doi:10.1111/j.1468-0289.1996.tb00578.xnce

Rueff, J. (1971). The monetary sin of the west. New York, NY: The Macmillan Company.

Simmel, G. (2004). The philosophy of money (Routledge and P. Kegan Eds.). New York, NY: Routledge.

Steil, B. (2013). The battle of Bretton Woods. Princeton, NJ: Princeton University Press.

Triffin, R. (1960). Gold and the dollar crisis: The future of convertibility. New Haven, CT: Yale University Press. 